\title{
Evaluation of Serum, Saliva and GCF Visfatin Levels in Chronic Periodontitis Patients with Uncontrolled /Controlled Type2 Diabetes Mellitus
}

\author{
Mustafa Cihan Yavuz(0000-0002-2861-8828) ${ }^{\alpha}$, Cenk Fatih Çanakçı(0000-0003-4620-6437) ${ }^{\beta}$
}

Selcuk Dent J, 2021; 8: 817-823 (Doi: 10.15311/selcukdentj. 1009374)

Basvuru Tarihi: 02 Aralık 2020 Yayına Kabul Tarihi: 22 Aralık 2020

\begin{abstract}
Evaluation of Serum, Saliva and GCF Visfatin Levels in Chronic Periodontitis Patients with Uncontrolled /Controlled Type2 Diabetes Mellitus
\end{abstract}

Background: The aim of this study is to investigate visfatin levels in serum, saliva and GCF samples of non-diabetic CP patients, CP patients with t2DM and ut2DM, and to evaluate of the relationship with clinical and biochemical parameters of CP.

Methods: Study protocol, 5 groups which each one were consisted of 15 subjects were planned: patients with both periodontal and systemic health (DM-P-); CP patients with systemic health $(\mathrm{DM}-\mathrm{P}+)$, periodontally healthy patients with diabetes $(D M+P-)$, patients with diabetes and $C P(D M+P+)$, patients with uncontrolled diabetes and $\mathrm{CP}(\mathrm{uDM}+\mathrm{P}+)$. Serum, saliva and GCF samples were collected and levels of visfatin, TNF- $\alpha$ and IL-1 $\beta$ were determined by ELISA.

Results: The highest levels of visfatin, TNF- $\alpha$ and IL-1 $\beta$ were seen in $(u D M+P+)$ group $(p>0.001)$. Significant positive correlations between GCF visfatin levels and GCF TNF- $\alpha$ and $\mathrm{IL}-1 \beta$ levels were detected in $(\mathrm{uDM}+\mathrm{P}+)$ group $(p<0.001)$.

Conclusion: Serum, saliva and GCF visfatin levels were highest in the uncontrolled diabetes group. Different studies are needed to clarify the effect of visfatin on glycemic control in patients with diabetes and its relationship with periodontal disease.

\section{KEYWORDS}

Visfatin, TNF- $\alpha$, IL-1 $\beta$, Diabetes mellitus, Chronic periodontitis

Periodontal diseases are chronic diseases, which are highly prevalent in the society and which can substantially lead to tissue and tooth loss by spreading to the dental support tissues. The most common and investigated diseases of the periodontium are chronic inflammatory conditions such as plaque-associated gingivitis and chronic periodontitis (CP). ${ }^{1} \quad \mathrm{CP}$ is a multifactorial inflammatory disease that develops after the symbiotic balance returns to dysbiosis. Bacteria initiate the change in periodontal health, but the severity of destruction of periodontal tissues is shaped by the response of the host tissue. ${ }^{2} \mathrm{CP}$ is affected by some systemic risk factors as well as local factors. Regarding periodontal diseases,

\section{öz}

Kontrol Altında ve Kontrol Altında Olmayan Tip 2 Diyabete Sahip Kronik Periodontitisli Bireylerde Tükürük, Serum ve GCF Visfatin Seviyelerinin İncelenmesi

Amaç: Bu çalışmanın amacı, metabolik kontrolleri iyi ve kötü diyabetik kronik periodontitisli hastaların ve non-diyabetik kronik periodontitisli hastaların DOS, tükürük ve serum örneklerinde visfatin seviyelerinin araştıııımasıdır.

Gereç ve Yöntemler: Bu çalışmada her biri 15 katılımcıdan oluşan 5 grup oluşturuldu; sistemik sağlıklı ve periodontal olarak sağlıklı bireylerin oluşturduğu grup (DM-P-), sistemik sağlıklı ve kronik periodontitisli grup (DM-P+), diyabetli ve periodontal olarak sağlıklı grup $(\mathrm{DM}+\mathrm{P}-)$ ile diyabetli ve kronik periodontitisli grup $(\mathrm{DM}+\mathrm{P}+)$, kontrolsüz diyabetli ve kronik periodontitisli grup (uDM+P+). Serum, tükürük ve DOS örneklerinin alınmasını takiben klinik periodontal parametreler kaydedildi. Lokal ve sistemik visfatin, TNF- $\alpha$ ve IL-1 $\beta$ düzeyleri biyokimyasal olarak ölçüldü.

Bulgular: En yüksek visfatin, TNF- $\alpha$ ve IL-1 $\beta$ seviyeleri $(\mathrm{UDM}+\mathrm{P}+)$ grubunda tespit edildi $(p>0.001)$. ( $(\mathrm{LDM}+\mathrm{P}+)$ grubunda DOS visfatin seviyeleri ile DOS TNF- $\alpha$ ve DOS IL-1 $\beta$ seviyeleri arasında istatistiksel olarak anlamlı pozitif korelasyonlar tespit edildi $(p<0.001)$.

Sonuç: Çalışma sonuçları diyabeti kontrol altında olmayan bireylerin serum, tükürük ve GCF visfatin seviyelerinin non-diyabetik bireylere göre yüksek olduğunu ortaya koymaktadır. Visfatinin tip 2 diyabetli hastalarda glisemik kontrolüne etkisini ve periodontal hastalıkla ilişkisini kesin olarak belirlemek ve netleştirmek için ileri çalışmalara intiyaç olduğu düşünülmektedir.

\section{ANAHTAR KELIMELER}

Visfatin, TNF- $\alpha$, IL-1 $\beta$, Diyabet, Kronik periodontitis

Diabetes Mellitus (DM) has been determined to be one of the most important systemic risk factors. ${ }^{3}$

$\mathrm{DM}$, a common disease seen in almost every population, is a chronic metabolic disease characterized by hyperglycemia due to the absence or deficiency of insulin. ${ }^{4}$ Although exacerbation of the periodontal disease, periodontal abscess, oral ulcers, moniliasis, burning sensation or pain in oral tissues were considered among its oral complications, studies on the mechanisms of the relationship between DM and periodontal disease continue to be updated. ${ }^{5}$ The probability of developing chronic periodontitis is high in individuals with diabetes, and it has been reported in the literature that periodontitis is the sixth most common complication of diabetes. In addition, the

\footnotetext{
${ }^{\alpha}$ Medeniyet University, Faculty of Dentistry, Department of Periodontology İstanbul, Turkey.

$\beta$ Atatürk University, Faculty of Dentistry, Department of Orthodontics Erzurum, Turkey.
} 
reverse is also true, that is, periodontitis complicates glycemic control in individuals with diabetes. In other words, there is a two-way relationship between periodontitis and diabetes. ${ }^{6}$

Adipose tissue is known to produce and release inflammatory factors. These factors and cytokines play significant roles in inflammation and immune response. Visfatin is one of the new adipocytokines, identified in recent years. ${ }^{7}$ Visfatin, discovered in 1994, is a $52 \mathrm{kD}$ adipokine protein, also known as pre-B cell colony-enhancing factor (PBEF) and nicotinamide phosphoribosyltransferase (NAMPT). ${ }^{7}$ Visfatin shows both immunoregulatory and proinflammatory properties by supporting B cell maturation. That is, it affects leukocyte activation and the production of proinflammatory cytokines. It has been suggested that during infection and inflammation, the production of IL$1 \beta$, TNF- $\alpha$, and IL- 6 can be induced by visfatin. ${ }^{8}$ Expression of visfatin is up-regulated in a variety of acute and chronic inflammatory diseases including rheumatoid arthritis, sepsis, acute lung injury, inflammation, inflammatory bowel disease and psoriasis and plays a key role in the persistence of inflammation through its capacity to inhibit neutrophil apoptosis. $^{9}$

High visfatin plasma levels have been reported in a group of patients with t2DM receiving hypoglycemic therapy..$^{10}$ In addition, in a recent study by Pradeep et al. ${ }^{12}$, higher visfatin levels were identified in individuals with periodontal disease compared with healthy subjects. Although the exact mechanisms by which visfatin affects insulin resistance and inflammation is not known, it is a fact that it induces the production of pro-inflammatory cytokines such as TNF- $\alpha$ and IL-1 $\beta$ and inhibits insulin signaling. ${ }^{13}$ Therefore, visfatin may be a worthwhile mediator in elucidating the relationship mechanism between diabetes and periodontitis, whose interactions are known clinically. Hence, the aim of this study is to investigation of visfatin levels in serum, saliva and GCF samples of chronic periodontitis patients with non-diabetic, controlled/uncontrolled DM, and evaluation of the relationship with clinical and biochemical parameters of periodontitis.

\section{MATERIALS AND METHODS}

\section{Patients selection and groups}

75 subjects aged between 32 and 69 who applied to Atatürk University Faculty of Dentistry, Department of Periodontology were included in this study and were divided into five groups as 15 subjects for each group. Ethical approval was obtained from Atatürk University Faculty of Dentistry Ethics Committee 04.04.2012 / 005. The consent form, which clearly conveys information about the content of the study and the procedures to be carried out, was read to all individuals, and their approval was obtained and signed. The exclusion criteria were as follows: (1) alchol and smoking; (2) pregnancy; (3) systemic diseases which may be reflected in the periodontium; (4) receiving surgical and non-surgical periodontal treatment; and (5) having taken medication in the last 6 months which may affect the periodontium. Individuals included in the study were divided into five groups regarding $\mathrm{HbA1c}$ level, clinical and radiographic periodontal evaluations.

1st group: Systemically and periodontally healthy individuals; (DM-P-) group

2nd group: Periodontally healthy patients with controlled DM (HbA1c <7); (DM+P-) group

3rd group: Systemically healthy chronic periodontitis patients; (DM-P+) group

4th group: Chronic periodontitis patients with controlled DM $(\mathrm{HbA} 1 \mathrm{c}<7)$; $(\mathrm{DM}+\mathrm{P}+)$ group

5th group: Chronic periodontitis patients with uncontrolled DM $(\mathrm{HbA} 1 \mathrm{c} \geq 7)$; (uDM+P+) group

\section{Clinical Evaluation}

Clinical measurements were performed at four points per tooth using a probe and recorded on a chart by the same periodontist. The following criteria were taken for the diagnosis of $\mathrm{CP}$; at least four teeth in each jaw, probing depths $\geq 5 \mathrm{~mm}$, clinical attachment levels $\geq 4$ $\mathrm{mm}$, bleeding on probing scores $>50 \%$, and $\geq 50 \%$ alveolar bone loss in at least two quadrants. ${ }^{13}$

The mean $\mathrm{HbA} 1 \mathrm{c}$ levels reported by the American diabetes association for patients with controlled DM was $<7$ and for patients with uncontrolled $\mathrm{DM} \geq 7 .{ }^{14}$

Anthropometric measurements included weight $(\mathrm{kg})$ and height $(\mathrm{m})$ of the patients to calculate the BMI $\left(\mathrm{kg} / \mathrm{m}^{2}\right)$. Obesity was defined as $\mathrm{BMI} \geq 30$ while being overweight was defined as BMI 25-29.9 and normal weight was defined as BMl ranging from 20 to 24.9 $\mathrm{kg} / \mathrm{m}^{2} .15$

In accordance with the study design, individuals with $\mathrm{BMI}$ value above 30 were excluded to eliminate the obesity factor.

The following clinical criteria were taken into account in patients with DM and periodontitis:

(1) patients who were diagnosed with uncontrolled DM and have not yet started treatment.

(2) controlled DM patients who received DM treatment 
for at least 1 year.

(3) patients with periodontitis do not have a history of periodontal treatment for the last 1 year.

\section{Collection of serum}

Blood samples were taken from the antecubital fossa from the individuals participating in our study for standardization while the patient was in a sitting position. The blood sample was allowed to clot at room temperature and, after $1 \mathrm{~h}$, serum was separated from blood by centrifugation at $3500 \mathrm{rpm} /$ speed for 5 minutes and kept in the freezer at $-80 \mathrm{C}$ until subsequent biochemical analyses.

\section{Collection of Saliva}

Unstimulated whole saliva (5 mL) was collected from each participant between 10:00 am and 12:00 pm. The patients were asked to swallow saliva first, and then allow the saliva to drain passively for 5 minutes over the lower lip into a sterile tube. Collected saliva was immediately placed on ice prior to freezing at 80C until additional measurement of salivary biochemical analyses was performed using enzymelinked immunosorbent assay (ELISA).

\section{Collection of GCF}

GCF samples were collected 2-3 hours after breakfast the day after the first examination to avoid contamination with blood caused by probing in the inflamed area. The sampling sites were sealed with cotton rolls and gently air dried. The paper strips were gently placed in the pocket for 30 seconds until minimal resistance was felt. All samples containing blood and saliva were discarded. The volume of the sample taken was measured and noted with the Periotron 8000 (Oraflow Inc. Plainview, NY, USA) device previously calibrated. The samples were immediately transferred to microcentrifuge tubes with $100 \mu \mathrm{l}$ phosphate buffered saline and stored at $-80^{\circ} \mathrm{C}$.

\section{Biochemical Assay}

Visfatin levels in serum, saliva, and GCF samples were made using a commercially produced measuring kit. (USCN Life Science, Wuhan, China) The measurement method was based on the standard sandwich enzyme-linked immune-sorbent assay (ELISA) technique. Visfatin measurement was made according to the measurement procedures recommended by the manufacturer. Micropipe was placed in the reader and the measurement was made rapidly at 450nm. (ELx800, BioTek, Winooski, VT.)

Total serum, saliva and GCF levels of TNF- $\alpha$ and IL-1 $\beta$ were determined by using a quantitative sandwich enzyme-linked immunosorbent assay (ELISA) kit. The absorbance values were determined by using an ELISA reader at $450 \mathrm{~nm}$. A standard curve was constructed by using standards provided in the kits, and the cytokine concentrations were calculated from the standard curve.

\section{Statistical Analyses}

The Kolmogorov-Smirnov test was used to evaluate the compliance of the data to normal distribution. Comparisons between groups were made using Kruskal-wallis test and Mann-Whitney $U$ test. Correlations between demographic, clinical and laboratory parameters were analyzed using the Pearson correlation test. All these statistical evaluations were made with the SPSS $^{\circledR} 17.0$ Windows $^{\circledR}$ program. A $p$ value of $<0.05$ was considered statistically significant.

\section{RESULTS}

The demographic findings of 75 individuals included in the study (38 males and 37 females) are shown in Table 1. The lowest mean age belonged to (DM-P-) group, whereas the highest mean age group was found in the $(\mathrm{uDM}+\mathrm{P}+)$ group. There were no statistically significant differences among the groups regarding the age averages $(p>0.05)$ (Table 1$)$.

BMI values did not indicate any statistically significant differences among the groups $(p>0.05)$ (Table 1).

HbA1c values of the (DM+P-) and $(\mathrm{DM}+\mathrm{P}+)$ groups were significantly higher than the (DM-P-) and $(\mathrm{DM}-\mathrm{P}+)$ groups, whereas the $\mathrm{HbA1c}$ value of $(\mathrm{uDM}+\mathrm{P}+)$ group was significantly highest than all the other groups $(p<0.05)(p<0.001)$ (Table 1$)$.

Table 1.

\section{Demographic findings of study groups}

\begin{tabular}{|lccccc|}
\hline & $\begin{array}{c}(\mathbf{D M}-\mathbf{P}-) \\
(\mathbf{n}=15)\end{array}$ & $\begin{array}{c}(\mathbf{D M}-\mathbf{P}+) \\
(\mathbf{n}=15)\end{array}$ & $\begin{array}{c}(\mathbf{D M}+\mathbf{P}-) \\
(\mathbf{n}=15)\end{array}$ & $\begin{array}{c}(\mathbf{D M}+\mathbf{P}+) \\
(\mathbf{n}=15)\end{array}$ & $\begin{array}{c}(\mathbf{u D M}+\mathbf{P}+) \\
(\mathbf{n}=15)\end{array}$ \\
\hline $\begin{array}{l}\text { Male/ } \\
\text { Female }\end{array}$ & $8: 7$ & $7: 8$ & $8: 7$ & $7: 8$ & $8: 7$ \\
\hline Years & $35.42 \pm 4.87$ & $36.63 \pm 4.33$ & $35.63 \pm 4.40$ & $36.90 \pm 4.54$ & $38.75 \pm 4.88$ \\
\hline $\begin{array}{l}\mathrm{BMI} \\
(\mathrm{kg} / \mathrm{m} 2)\end{array}$ & $23.53 \pm 2.39$ & $23.71 \pm 1.65$ & $24.98 \pm 2.00$ & $25.07 \pm 2.91$ & $26.93 \pm 2.64$ \\
\hline $\begin{array}{l}\mathrm{HbA1c} \\
(\%)\end{array}$ & $4.8 \pm 0.76$ & $5.2 \pm 0.84$ & $6.9 \pm 0.81 *$ & $6.4 \pm 0.97^{*}$ & $10.4 \pm 1.19^{* *}$ \\
\hline
\end{tabular}

The mean values together with their standard deviations of $\mathrm{PI}, \mathrm{GI}, \mathrm{BI}, \mathrm{PD}$ and $\mathrm{CAL}$ values of all groups were presented in Table 2.

It was observed that all of the clinical parameters were statistically significantly higher in the groups with periodontitis groups $(\mathrm{DM}-\mathrm{P}+),(\mathrm{DM}+\mathrm{P}+)$ and $(\mathrm{uDM}+\mathrm{P}+)$, when compared to the periodontally healthy groups $(\mathrm{DM}-\mathrm{P}-),(\mathrm{DM}+\mathrm{P}-)(\mathrm{p}<0.05)$ (Table 2).

There were no statistically significant differences regarding $\mathrm{PI}, \mathrm{GI}, \mathrm{BI}, \mathrm{PD}$ and $\mathrm{CAL}$ values between all three groups with periodontitis and between periodontally healthy groups $(p>0.05)$ (Table 2$)$ 
Table 2.

\section{Clinical parameters of study groups}

\begin{tabular}{|c|c|c|c|c|c|}
\hline & $\begin{array}{l}(\mathrm{DM}-\mathrm{P}-) \\
(\mathrm{n}=15)\end{array}$ & $\begin{array}{c}(\mathrm{DM}-\mathrm{P}+) \\
(\mathrm{n}=15)\end{array}$ & $\begin{array}{c}(\mathrm{DM}+\mathrm{P}-) \\
(\mathrm{n}=15)\end{array}$ & $\begin{array}{c}(\mathrm{DM}+\mathrm{P}+) \\
(\mathrm{n}=15)\end{array}$ & $\begin{array}{c}(\mathrm{uDM}+\mathrm{P}+) \\
(\mathrm{n}=15)\end{array}$ \\
\hline PI & $0.03 \pm 0.01$ & $2.29 \pm 0.19$ * & $0.05 \pm 0.04$ & $2.37 \pm 0.19$ * & $2.54 \pm 0.23$ * \\
\hline GI & $0.06 \pm 0.01$ & $1.82 \pm 0.18$ * & $0.08 \pm 0.03$ & $1.87 \pm 0.26$ * & $1.85 \pm 0.22$ * \\
\hline BOP (\%) & $7.22 \pm 6.05$ & $86.07 \pm 4.75^{\star}$ & $7.25 \pm 6.12$ & $85.29 \pm 5.44^{\star}$ & $86.39 \pm 5.87^{*}$ \\
\hline PD & $1.29 \pm 0.18$ & $4.32 \pm 0.38^{\star}$ & $1.31 \pm 0.29$ & $4.24 \pm 0.41^{*}$ & $4.27 \pm 0.38^{\star}$ \\
\hline CAL & $1.64 \pm 0.41$ & $4.52 \pm 0.53^{\star}$ & $1.68 \pm 0.47$ & $4.55 \pm 0.46^{\star}$ & $4.76 \pm 0.43^{*}$ \\
\hline
\end{tabular}

The mean and standard deviation values of visfatin, TNF- $\alpha$ ve IL- $1 \beta$ levels of serum and saliva were presented in Table 3.

Serum visfatin level was found to be statistically significantly higher in the $(\mathrm{uDM}+\mathrm{P}+)$ group than in the other groups $(p<0.001)$. There was no statistically significant difference between $(\mathrm{DM}+\mathrm{P}-)$ and $(\mathrm{DM}+\mathrm{P}+)$ groups. Similarly, no statistically significant difference was observed between (DM-P-) and (DM-P +) groups, whereas serum visfatin levels were statistically significantly higher in $(D M+P-)$ and $(D M+P+)$ groups when compared to (DM-P-) and $(D M-P+)$ groups $(p<0.001)$. Salivary visfatin level of $(u D M+P+)$ group was determined to be statistically significantly increased in comparison with the other groups $(p<0.001)$. There was no statistically significant difference between (DM-P-) and (DM-P +) groups, and the lowest values were observed in these groups. On the other hand, salivary visfatin level was found to be statistically significantly higher in $(\mathrm{DM}+\mathrm{P}+)$ group compared to $(\mathrm{DM}+\mathrm{P}-)$ group, whereas salivary visfatin levels were found to be statistically significantly increased in the $\left(\mathrm{DM}+\mathrm{P}_{-}\right)$ve $(\mathrm{DM}+\mathrm{P}+)$ groups when compared to the (DM-P-) ve (DM-P+) groups $(p<0.001)$ (Table 3). Visfatin level in GCF was found to be statistically significantly higher in the $(u D M+P+)$ group in comparison with the other groups $(p<0.001)$. There was no statistically significant difference between the $(D M+P+)$ and $(D M-P+)$ group. Similarly, visfatin levels in GCF were found to be statistically significantly higher in the $(\mathrm{DM}-\mathrm{P}+)$ and $(\mathrm{DM}+\mathrm{P}+)$ groups compared to the (DM-P-) and (DM+P-) groups, while there was no statistically significant difference between the (DM-P-) and (DM+P-) groups $(p<0.001)$ (Table 3$)$.

Serum TNF- $\alpha$ level was found to be statistically significantly higher in $(\mathrm{UDM}+\mathrm{P}+)$ group whereas there were no statistically significant differences among the other groups (Table 3). Salivary TNF- $\alpha$ level did not have any statistically significant difference among the groups (Table 3). GCF TNF- $\alpha$ level was found to be statistically significantly higher in the $(u D M+P+)$ group when compared to the other groups $(p<0.001)$. GCF TNF- $\alpha$ levels of $(D M+P-)$ and (DM$P-)$ groups were not found to be statistically significantly different and the lowest values were determined in these groups. GCF TNF- $\alpha$ level was found to be statistically significantly higher in the $(\mathrm{DM}+\mathrm{P}+)$ group when compared to the $(\mathrm{DM}-\mathrm{P}+)$ group, whereas GCF TNF- $\alpha$ levels were found to be statistically significantly higher in the $(D M+P+)$ ve $(D M-P+)$ groups compared to the $(D M+P-)$ ve $(D M-$ P-) groups $(p<0.001)($ Table 3$)$.

Serum and salivary IL-1 $\beta$ levels were not found to be statistically significantly different between the groups (Table 3). GCF IL-1 $\beta$ level was observed to be statistically significantly higher in $(\mathrm{UDM}+\mathrm{P}+)$ group when compared to the other groups $(p<0.001)$. GCF IL-1 $\beta$ level was not found to be statistically significantly different between $(D M+P-)$ and (DM-P-) groups, while the lowest values were determined in these groups. On the other hand, GCF IL-1 $\beta$ level was found to be statistically significantly higher in $(\mathrm{DM}+\mathrm{P}+)$ group than $(\mathrm{DM}-$ $\mathrm{P}+$ ) group, whereas it was found to be statistically significantly higher in $(D M+P+)$ and $(D M-P+)$ groups when compared to (DM+P-) ve (DM-P-) groups $(p<0.001)($ Table 3$)$.

Table 3.

\section{Serum, saliva and GCF Visfatin, TNF- $\alpha$ and IL-1 $\beta$ levels of study groups}

\begin{tabular}{|c|c|c|c|c|c|}
\hline & $\begin{array}{l}(\mathrm{DM}-\mathrm{P}-) \\
(\mathrm{n}=15)\end{array}$ & $\begin{array}{c}(\mathrm{DM}-\mathrm{P}+) \\
(\mathrm{n}=15)\end{array}$ & $\begin{array}{c}(\mathrm{DM}+\mathrm{P}-) \\
(\mathrm{n}=15)\end{array}$ & $\begin{array}{c}(\mathrm{DM}+\mathrm{P}+) \\
(\mathrm{n}=15)\end{array}$ & $\begin{array}{c}\left(\begin{array}{c}(\mathrm{uDM}+\mathrm{P}+) \\
(\mathrm{n}=15)\end{array}\right.\end{array}$ \\
\hline $\begin{array}{l}\text { Serum } \\
\text { Visfatin }\end{array}$ & $34.86 \pm 11.91^{\mathrm{a}}$ & $32.92 \pm 9.48^{\mathrm{a}}$ & $44.60 \pm 9.83^{b}$ & $45.59 \pm 10.80^{b}$ & $60.49 \pm 16.53^{c}$ \\
\hline TNF- $\alpha$ & $1.46 \pm 0.21^{a}$ & $1.49 \pm 0.19^{\mathrm{a}}$ & $1.45 \pm 0.23^{\mathrm{a}}$ & $1.45 \pm 0.16^{a}$ & $1.91 \pm 0.30^{b}$ \\
\hline IL-1 $\beta$ & $1.44 \pm 0.15^{\mathrm{a}}$ & $1.43 \pm 0.14^{\mathrm{a}}$ & $1.45 \pm 0.28^{\mathrm{a}}$ & $1.43 \pm 0.26^{a}$ & $1.46 \pm 0.22^{\mathrm{a}}$ \\
\hline $\begin{array}{l}\text { Saliva } \\
\text { Visfatin }\end{array}$ & $39.13 \pm 11.70^{\mathrm{a}}$ & $41.63 \pm 9.29^{\mathrm{a}}$ & $49.97 \pm 16.42^{b}$ & $57.30 \pm 10.25^{c}$ & $70.88 \pm 13.31^{d}$ \\
\hline TNF- $\alpha$ & $1.44 \pm 0.22^{\mathrm{a}}$ & $1.47 \pm 0.34^{\mathrm{a}}$ & $1.49 \pm 0.41^{\mathrm{a}}$ & $1.46 \pm 0.29^{\mathrm{a}}$ & $1.49 \pm 0.18^{\mathrm{a}}$ \\
\hline $\mathrm{IL}-1 \beta$ & $1.48 \pm 0.13^{\mathrm{a}}$ & $1.47 \pm 0.12^{\mathrm{a}}$ & $1.51 \pm 0.17^{\mathrm{a}}$ & $1.50 \pm 0.18^{\mathrm{a}}$ & $1.51 \pm 0.24^{\mathrm{a}}$ \\
\hline $\begin{array}{l}\text { GCF } \\
\text { Visfatin }\end{array}$ & $55.97 \pm 11.83^{\mathrm{a}}$ & $70.31 \pm 14.51^{b}$ & $58.77 \pm 9.04^{\mathrm{a}}$ & $73.56 \pm 8.75^{b}$ & $85.04 \pm 9.11^{c}$ \\
\hline TNF- $\alpha$ & $1.27 \pm 0.27^{\mathrm{a}}$ & $2.29 \pm 0.20^{b}$ & $1.33 \pm 0.31^{\mathrm{a}}$ & $2.63 \pm 0.30^{c}$ & $2.96 \pm 0.20^{d}$ \\
\hline $\mathrm{IL}-1 \beta$ & $1.40 \pm 0.30^{\mathrm{a}}$ & $1.86 \pm 0.22^{b}$ & $1.41 \pm 0.32^{\mathrm{a}}$ & $2.11 \pm 0.35^{c}$ & $2.30 \pm 0.47^{d}$ \\
\hline
\end{tabular}

\section{DISCUSSION}

There are increasing reports in the literature on the relationship between visfatin, an adipocytokin with proinflammatory and immunomodulating properties, and both DM and destructive periodontal disease. ${ }^{16-}$ 18 Visfatin is generally secreted by the adipose tissue and can also be produced by neutrophils and macrophages. ${ }^{19}$ The evidences showed that visfatin levels of biological fluids increased significantly in individuals with DM, individuals with chronic periodontitis, and individuals with both diseases, compared to healthy controls. ${ }^{11,17}$ Destructive periodontal disease progression may play a 
significant role in predicting high-risk individuals for the most common diseases of the present era like diabetes. The possible role of visfatin, which is thought to play a role in the pathogenesis of DM and periodontitis, in the interaction mechanism known to exist between both diseases should be discussed.

In the present study; serum, saliva and GCF visfatin levels were significantly highest in uncontrolled DM group. In addition, serum visfatin levels were significantly higher in controlled DM groups, patients with/without chronic periodontitis than non-diabetic groups. Saliva visfatin level was significantly higher in $(\mathrm{DM}+\mathrm{P}+)$ group than $\left(\mathrm{DM}+\mathrm{P}_{-}\right)$and non-diabetic groups. Controlled DM group without chronic periodontitis had significantly high saliva visfatin level compared to the non-diabetic groups. On the other hand, GCF visfatin levels were significantly higher in the CP groups, patients with/without controlled DM compared to the periodontally healthy groups. The results of this study regarding visfatin levels are consistent with the results of previous studies conducted on individuals with chronic periodontitis, diabetes and both diseases. ${ }^{17}$ As an important difference in our study; an additional group of individuals with uncontrolled diabetes and periodontitis was formed and the highest serum, saliva and GCF visfatin levels were detected in this group. The continuation of uncontrolled diabetes and the existence of destructive periodontal diseases in these patients can significantly increase the interaction of both diseases. As far as we know from studies investigating the relationship between periodontal diseases and diabetes, the treatment of periodontitis contributes to the control of diabetes and the presence of untreated periodontitis in patients with controlled diabetes poses a risk for the maintain metabolic control. The findings of our study regarding visfatin levels may be the reflection of the proven and/or predicted relationship between metabolic control and destructive periodontal diseases on serum and oral biological fluids.

In periodontal diseases, many inflammatory biomarkers are present in serum, saliva and GCF. Visfatin is an inflammatory mediator that induces the synthesis of proinflammatory cytokines and acts as a chemotactic factor. This cytokine can induce the secretion of TNF- $\alpha$ in monocytes and also it has been demonstrated that IL-1 $\beta$ increases the visfatin concentration in chondrocytes. In present study; serum and GCF TNF- $\alpha$ levels were significantly highest in uncontrolled DM group, patients with chronic periodontitis. In addition, GCF TNF- $\alpha$ levels were significantly higher in CP groups, patients with/without controlled DM than periodontally healthy groups. CP group with controlled DM had significantly high GCF TNF- $\alpha$ level compared to the CP group without controlled DM. On the other hand, GCF IL-1 $\beta$ level was significantly highest in uncontrolled DM group, patients with chronic periodontitis. GCF IL-1 $\beta$ levels were significantly higher periodontitis. GCF IL-1 $\beta$ levels were significantly higher in CP groups, patients with/without controlled DM than periodontally healthy groups. CP group with controlled DM had significantly high GCF IL-1 $\beta$ level compared to the CP group without controlled DM.

Previous studies investigating the relationship between periodontal diseases and diabetes have shown that a number of cytokines are produced in response to systemic LPS exposure. ${ }^{20}$ Two principal cytokines involved in this response are TNF- $\alpha$ and IL-1 $\beta$. The results of this study regarding cytokines levels are consistent with the results of previous studies conducted on individuals with chronic periodontitis, diabetes and both diseases. ${ }^{21}$ Visfatin has been proved to induce TNF- $\alpha$ and IL- 6 in human monocytes and stimulate to secret inflammatory mediators and proteases by various intracellular pathways. It is generally accepted that infection results in a state of insulin resistance and that bacterial LPS has a significant effect on insulin sensitivity. The release of IL- $1 \beta$ and TNF- $\alpha$ in response to bacteremia/endotoxemia has numerous metabolic effects in addition to hyper lipidemia. If so, the findings of present study related with cytokines levels shown complex interaction between metabolic control and periodontal inflammation activity in uncontrolled DM patients with periodontitis. The key role of this complex interaction may be explained by elevated visfatin levels with potent activity for releasing IL- $1 \beta$ and TNF- $\alpha$ as a response to poor metabolic control. In addition, even higher levels of IL- $1 \beta$ and TNF- $\alpha$ in patients with DM and periodontitis, which are already at increased in destructive periodontal diseases, has a risk for maintain metabolic control and at the same time for successfully treatment of periodontitis.

In the present study, clinic periodontal parameters (GI, PI, PD and CAL) were found significantly higher in CP groups than periodontally healthy groups as expected, but no significant differences were seen among CP groups. No correlation between clinical periodontal parameters and biochemical parameters of biological fluids were detected. Clinical parameters such as GI, PI, PD and CAL can provide information on the severity of periodontitis, they do not measure disease activity. Our findings regarding correlation among clinical parameters and biochemical parameters may be sign that, visfatin levels are not related with the severity of periodontal disease. However, significantly positive correlations between GCF visfatin levels and both GCF TNF- $\alpha$ and GCF L- $1 \beta$ levels suggest a promising finding the relationship between periodontal disease activation and visfatin in uncontrolled DM group, patients with periodontitis (Table 4). 
Table 4. Correlations among biochemical parameters in
$(u D M+P+)$ group

\begin{tabular}{|c|c|c|}
\hline & GCF TNF- $\alpha$ & GCF IL- $1 \beta$ \\
\hline GCF Visfatin & 0.829 & 0.802 \\
\hline GCF TNF- $\alpha$ & & 0.647 \\
\hline
\end{tabular}

It has been reported that non-surgical periodontal therapy to reduce visfatin levels in saliva, serum, and GCF compared to baseline. ${ }^{22,23}$ In addition, in a study conducted in patients with diabetes, it was reported that $\mathrm{HbA1C}$ level decreased at 6 months after nonsurgical periodontal treatment, and it was added that visfatin may have affected this decrease. ${ }^{24}$ In this study, unlike other studies, there was also an uncontrolled t2DM group in the study groups. In a study, it was reported that the serum levels of visfatin was higher in the uncontrolled tip2DM group than in the controlled t2DM group. ${ }^{25}$ Since it has been reported in previous studies that a decrease in visfatin levels after periodontal treatment, a new study including the uncontrolled t2DM group can be designed and investigated how visfatin affects glycemic control after periodontal treatment.

The absence of gingivitis and aggressive periodontitis groups can be stated as the limitation of this study. The authors recommend that new studies with larger sample size be conducted according to the new classification of periodontal and peri-implant diseases and conditions 2017.

\section{CONCLUSION}

In this study, serum, saliva and GCF visfatin levels were measured in groups of controlled and uncontrolled diabetic individuals with/without periodontitis. The possible efficacy of visfatin, which is thought to play an important role in the pathogenesis of both diseases, was evaluated in the interaction between the two diseases. There are many molecular mechanisms in the proven clinical relationship between both diseases that are not yet fully explained. Results from our study suggest that visfatin is a promising molecule for both destructive periodontal diseases and DM, and also the complex interaction between them. It has the potential to be used as a marker in the diagnosis and treatment strategy of both diseases and also in the maintenance of treatment. However, it is clear that further studies are required to shed light on the subject. 


\section{REFERENCES}

1. Lang, N. P., Schätzle, M. A., \& Löe, H. (2009). Gingivitis as a risk factor in periodontal disease. Journal of clinical periodontology, 36, 3-8.

2. Buduneli, N. (2021). Environmental factors and periodontal microbiome. Periodontology 2000, 85(1), 112-125.

3. Genco, R. J., Graziani, F., \& Hasturk, H. (2020). Effects of periodontal disease on glycemic control, complications, and incidence of diabetes mellitus. Periodontology 2000, 83(1), 59-65.

4. Gabir, M. M., Hanson, R. L., Dabelea, D., Imperatore, G., Roumain, J., Bennett, P. H., \& Knowler, W. C. (2000). The 1997 American Diabetes Association and 1999 World Health Organization criteria for hyperglycemia in the diagnosis and prediction of diabetes. Diabetes care, 23(8), 1108-1112.

5. Löe, H. (1993). Periodontal disease: the sixth complication of diabetes mellitus. Diabetes care, 16(1), 329-334.

6. Grossi, S. G., \& Genco, R. J. (1998). Periodontal disease and diabetes mellitus: a two-way relationship. Annals of periodontology, 3(1), 51-61.

7. Fukuhara, A., Matsuda, M., Nishizawa, M., Segawa, K., Tanaka, M., Kishimoto, K., ... \& Shimomura, I. (2005). Visfatin: a protein secreted by visceral fat that mimics the effects of insulin. Science, 307(5708), 426-430.

8. Ognjanovic, S., Bao, S., Yamamoto, S. Y., GaribayTupas, J., Samal, B., \& Bryant-Greenwood, G. D. (2001). Genomic organization of the gene coding for human pre-B-cell colony enhancing factor and expression in human fetal membranes. Journal of molecular endocrinology, 26(2), 107-118.

9. Moschen, A. R., Kaser, A., Enrich, B., Mosheimer, B., Theurl, M., Niederegger, H., \& Tilg, H. (2007). Visfatin, an adipocytokine with proinflammatory and immunomodulating properties. The Journal of Immunology, 178(3), 1748-1758.

10. Hammarstedt, A., Pihlajamaki, J., Rotter Sopasakis, V., Gogg, S., Jansson, P. A., Laakso, M., \& Smith, U. (2006). Visfatin is an adipokine, but it is not regulated by thiazolidinediones. The Journal of Clinical Endocrinology \& Metabolism, 91(3), 1181-1184.

11. Pradeep, A. R., Raghavendra, N. M., Prasad, M. R., Kathariya, R., Patel, S. P., \& Sharma, A. (2011). Gingival crevicular fluid and serum visfatin concentration: their relationship in periodontal health and disease. Journal of periodontology, 82(9), 13141319.

12. Heo, Y. J., Choi, S. E., Jeon, J. Y., Han, S. J., Kim, D. J., Kang, Y., ... \& Kim, H. J. (2019). Visfatin induces inflammation and insulin resistance via the NF-kB and STAT3 signaling pathways in hepatocytes. Journal of diabetes research, 2019.

13. Armitage, G. C. (1999). Development of a classification system for periodontal diseases and conditions. Annals of periodontology, 4(1), 1-6.

14. Care, D. (2010). Executive summary: standards of medical care in diabetes-2010. Diabetes Care, 33(supplement 1), S4-S10.
15. Leong, K. S., \& Wilding, J. P. (1999). Obesity and diabetes. Best Practice \& Research Clinical Endocrinology \& Metabolism, 13(2), 221-237.

16. Nourbakhsh, M., Nourbakhsh, M., Gholinejad, Z., \& Razzaghy-Azar, M. (2015). Visfatin in obese children and adolescents and its association with insulin resistance and metabolic syndrome. Scandinavian Journal of Clinical and Laboratory Investigation, 75(2), 183-188.

17. Pradeep, A. R., Raghavendra, N. M., Sharma, A., Patel, S. P., Raju, A., Kathariya, R., ... \& Naik, S. B. (2012). Association of serum and crevicular visfatin levels in periodontal health and disease with type 2 diabetes mellitus. Journal of periodontology, 83(5), 629-634.

18. Bahammam, M. A., \& Attia, M. S. (2018). Effects of systemic simvastatin on the concentrations of visfatin, tumor necrosis factor- $\alpha$, and interleukin- 6 in gingival crevicular fluid in patients with type 2 diabetes and chronic periodontitis. Journal of immunology research, 2018.

19. McGlothlin, J. R., Gao, L., Lavoie, T., Simon, B. A., Easley, R. B., Ma, S. F., ... \& Ye, S. Q. (2005). Molecular cloning and characterization of canine pre-Bcell colony-enhancing factor. Biochemical genetics, 43(3-4), 127-141.

20. Nishimura, F., Iwamoto, Y., Mineshiba, J., Shimizu, A., Soga, Y., \& Murayama, Y. (2003). Periodontal disease and diabetes mellitus: the role of tumor necrosis factor$\alpha$ in a 2-way relationship. Journal of periodontology, 74(1), 97-102.

21. Graves, D. T., \& Cochran, D. (2003). The contribution of interleukin-1 and tumor necrosis factor to periodontal tissue destruction. Journal of periodontology, 74(3), 391-401.

22. Saseendran, G., Abraham, S., Nair, A. M., \& Reejamol, M. K. (2021). Comparative evaluation of salivary visfatin levels in healthy and periodontally diseased patients before and after scaling and root planing. Journal of Pharmacy and Bioallied Sciences, 13(5), 624

23. Raghavendra, N. M., Pradeep, A. R., Kathariya, R., Sharma, A., Rao, N. S., \& Naik, S. B. (2012). Effect of non-surgical periodontal therapy on gingival crevicular fluid and serum visfatin concentration in periodontal health and disease. Disease markers, 32(6), 383-388.

24. Wu, Y., Chen, L., Wei, B., Luo, K., \& Yan, F. (2015). Effect of non-surgical periodontal treatment on visfatin concentrations in serum and gingival crevicular fluid of patients with chronic periodontitis and type 2 diabetes mellitus. Journal of periodontology, 86(6), 795-800.

25. El-Shaer, O. S., Belal, K. M., \& Hesham, A. I. (2012). Increased serum visfatin levels in patients with type 2 diabetic patients. Life Science Journal, 93.
Mustafa Cihan YAVUZ
Medeniyet University
Faculty of Dentistry
Department of Periodontology
İstanbul, Turkey
Phone : +90 5056426856
E-mail : muscyz111@gmail.com 